\title{
INTRACELLULAR ION CONCENTRATIONS OF EPI- THELIAL CELLS IN RAT SMALL INTESTINE EFFECTS OF EXTERNAL POTASSIUM IONS AND UPHILL TRANSPORTS OF GLUCOSE AND GLYCINE
}

\author{
Yasunobu OKADA, Akihiko IrIMAJIRI, and Akira INOUYE \\ Department of Physiology, Kyoto University School of Medicine, \\ Kyoto 606, Japan
}

\begin{abstract}
The water content $(V)$ and the concentrations of $\mathrm{K}^{+}, \mathrm{Na}^{+}$, and $\mathrm{Cl}^{-}$in the epithelial cells of rat small intestine $\left([\mathrm{K}]_{\mathrm{i}},[\mathrm{Na}]_{\mathrm{i}}\right.$, and $\left.[\mathrm{Cl}]_{\mathrm{i}}\right)$ were measured in high $\mathrm{K}^{+}$media and in the presence of glucose or glycine $(20 \mathrm{mM})$. Raised external $\mathrm{K}^{+}$concentrations brought about increases in $V$. Parallel with swelling of the cell, increases in $[\mathrm{K}]_{\mathrm{i}}$ and $[\mathrm{Cl}]_{\mathrm{i}}$ and decreases in $[\mathrm{Na}]_{i}$ were observed. Such a pattern of changes in $[\mathrm{K}]_{i},[\mathrm{Na}]_{i}$, and $[\mathrm{Cl}]_{\mathrm{i}}$ was concordant with that expected from the $\mathrm{K}^{+}$-induced depolarization and the permeability properties of the cell membranes. In the presence of D-glucose or glycine, remarkable increases in $V$ were observed, which resulted in concomitant decreases in $[\mathrm{K}]_{i},[\mathrm{Na}]_{i}$, and $[\mathrm{Cl}]_{i}$. Assuming the osmotic balance between intra- and extracellular fluids, the concentrations of accumulated solutes within the cell as well as the net gain of these ions were estimated. The results demonstrated that the accumulated solute was in an osmotically active form, resulting in cell swelling with concomitant decreases in $[\mathrm{Cl}]_{i}$, while the net gain of $\mathrm{Na}^{+}$ and $\mathrm{K}^{+}$in the cells occurred despite apparent decreases in $[\mathrm{Na}]_{\mathrm{i}}$ and $[\mathrm{K}]_{\mathrm{i}}$.
\end{abstract}

It has been well established that many sugars and amino acids are transported against a concentration gradient across the mucosal cell membrane in the small intestine (WILSON, 1962), and that $\mathrm{Na}^{+}$transport is closely related to this mechanism (SCHultz and CuRran, 1970; Hoshi, 1972). It is very likely, therefore, that actively transported solutes induce changes in ion concentrations within the intestinal epithelial cell. On the other hand, sugars and amino acids actively transported by the epithelial cells have also been known to produce so-called "evoked-potential" (BARRY et al., 1964; Schultz and ZALUSKY, 1964; LyON and Crane, 1966; Hoshi

Received for publication May 4, 1976

岡田泰伸, 入交昭彦, 井上章 
and Komatsu, 1968), which should be closely associated with the transport mechanism. It is of great importance for understanding such an electrogenesis to evaluate the changes in ion concentrations accompanied by solute transports. Many investigators have reported changes in the intracellular concentrations of $\mathrm{K}^{+}$ and $\mathrm{Na}^{+}\left([\mathrm{K}]_{\mathrm{i}},[\mathrm{Na}]_{\mathrm{i}}\right)$ associated with active transport of organic solutes in small intestines, but did not measure the $\mathrm{Cl}^{-}$concentration $\left([\mathrm{Cl}]_{\mathrm{i}}\right)$ (ScHultz et al., 1966; Koopman and Schultz, 1969; Csáky and Esposito, 1969; Armstrong et al., 1970; LeE and ARMSTRONG, 1972).

Our previous electrophysiological studies of the intestinal epithelial cell have suggested that the permeability properties of the cell membrane were remarkably altered by an increase in the extracellular $\mathrm{K}^{+}$concentration (OKADA et al., 1975, 1976), which should necessarily produce significant changes in the intracellular ion concentrations. In fact, we could show, qualitatively at least, that such changes in $[\mathrm{K}]_{i}$ and $[\mathrm{Na}]_{i}$ were in accord with the changes in the membrane potentials observed (OKADA et al., 1976). Moreover, our results showed that $\mathrm{Cl}^{-}$was rapidly and passively distributed between extra- and intracellular phases, making no significant contribution to the membrane potential in the steady state (OKADA et al., $1975,1976)$. Thus the measurement of $[\mathrm{Cl}]_{\mathrm{i}}$ is important for an understanding of the pattern of changes in intracellular ions under various conditions.

In view of these previous findings, we attempted here to examine the changes in $[\mathrm{K}]_{i},[\mathrm{Na}]_{\mathrm{i}}$ and $[\mathrm{Cl}]_{\mathrm{i}}$ in rat small intestine which occurred in association with the transport of D-glucose or glycine as well as with high levels of external $\mathrm{K}^{+}$, in order to obtain more quantitative information thereon.

\section{MATERIAL AND METHODS}

All experiments were performed on the intestinal epithelia of adult rats of either sex which had been starved for $24-48 \mathrm{hr}$ with water ad libitum. After anesthetization with ether, the abdominal cavity was opened by a midline incision. Intestinal contents were removed using a syringe and fresh buffered saline, and the sheet of intestinal mucosa was mounted on a lucite frame as described elsewhere (OKADA et al., 1976).

A full description of the procedure of ion analysis has been given in a previous report (OKADA et al., 1976). Briefly, the tissue mounted on the frame was incubated in the test solution containing ${ }^{14} \mathrm{C}$-inulin for $10 \mathrm{~min}$, which was oxygenated by bubbling humidified $\mathrm{O}_{2}$ and kept at $37^{\circ} \mathrm{C}$. After blotting the tissue on dry filter paper, the mucosal layer was scraped off with a cover glass and the wet weight $(W)$ was measured immediately with a torsion balance. Then the scraped sample was either extracted with $0.1 \mathrm{~N} \mathrm{HNO}_{3}$ at $37^{\circ} \mathrm{C}$ for 1-2 days and subjected to ion analyses, or dried at $105^{\circ} \mathrm{C}$ overnight to obtain the dry weight $(D)$. The activity of ${ }^{14} \mathrm{C}$ was estimated by liquid scintillation counting, $\mathrm{Na}^{+}$and $\mathrm{K}^{+}$contents by flame photometry, and $\mathrm{Cl}^{-}$content with a chloridometer. 
The tissue water per $\mathrm{g}$ wet tissue $(\theta)$ is given as $(W-D) / W$ and the intracellular water per $\mathrm{g}$ wet tissue as $\theta \cdot \phi$, where $\phi$ is the inulin-inaccesible space obtained from the inulin space measurements. Assuming that the jon concentrations in the inulin space were identical to those in the incubation media $\left([\mathrm{K}]_{0},[\mathrm{Na}]_{0}\right.$ and $\left.[\mathrm{Cl}]_{0}\right)$, the intracellular concentrations of $\mathrm{K}^{+}, \mathrm{Na}^{+}$and $\mathrm{Cl}^{-}\left([\mathrm{K}]_{\mathrm{i}},[\mathrm{Na}]_{\mathrm{i}}\right.$ and $\left.[\mathrm{Cl}]_{\mathrm{i}}\right)$ were calculated from the analytical data and the amount of intracellular water thus estimated. The cell water content per $g$ dry tissue was calculated as $\theta \cdot \phi /(1$ $\theta)$.

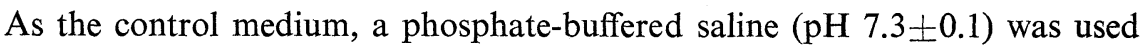
which had the following composition (in $\mathrm{mM}$ ): $127.0 \mathrm{NaCl}, 2.7 \mathrm{KCl}, 0.9 \mathrm{CaCl}_{2}$, $0.5 \mathrm{MgCl}_{2}, 8.0 \mathrm{Na}_{2} \mathrm{HPO}_{4}, 1.5 \mathrm{KH}_{2} \mathrm{PO}_{4}$ and 20.0 mannitol. Changes in potassium concentrations of the bathing solution were made by replacing all or a part of $\mathrm{NaCl}$, $\mathrm{Na}_{2} \mathrm{HPO}_{4}$ and $\mathrm{KH}_{2} \mathrm{PO}_{4}$ with $\mathrm{KCl}, \mathrm{K}_{2} \mathrm{HPO}_{4}$ and $\mathrm{NaH}_{2} \mathrm{PO}_{4}$, respectively, (or vice versa) on an equimolar basis. Application of D-glucose or glycine was made by replacing mannitol with the sugar or the amino acid respectively.

All data presented here were given as means $\pm S E$.

\section{RESULTS}

\section{Cell water content}

When the tissues were incubated in the control medium, the values of total tissue water $(\theta)$ of rat duodenum, jejunum and ileum were $80.9,80.7$ and $83.0 \%$, respectively, while their inulin-inaccessible spaces $(\phi)$ were $0.87,0.86$ and 0.81 , respectively (Table 1 ). Thus the cell water volume $(V)$ computed to the duodenum,

Table 1. Effect of D-glucose $(20 \mathrm{~mm})$ and glycine $(20 \mathrm{~mm})$ on the total tissue water $(\theta)$, the inulin-inaccessible space $(\phi)$ and the cell water content $(V)$.

\begin{tabular}{llllll}
\hline Tissue & Condition & \multicolumn{1}{c}{$\theta(\%)$} & $\phi$ & $V(\mathrm{ml} / \mathrm{g}$ dry weight $)$ & $\begin{array}{c}\text { Relative } \\
\text { swelling }\end{array}$ \\
\hline \multirow{3}{*}{ Duodenum } & Control & $80.9 \pm 0.2(10)$ & $0.877 \pm 0.008(6)$ & $3.73 \pm 0.05(10)$ & 1.00 \\
& Glucose & $87.0 \pm 2.5(5)$ & $0.825 \pm 0.009(5)$ & $6.46 \pm 1.24(5)^{*}$ & 1.70 \\
& Glycine & $87.2 \pm 0.6(5)^{*}$ & $0.830 \pm 0.017(5)$ & $5.12 \pm 0.23(5)^{*}$ & 1.56 \\
\hline \multirow{3}{*}{ Jejunum } & Control & $80.7 \pm 0.4(5)$ & $0.854 \pm 0.004(5)$ & $3.64 \pm 0.06(5)$ & 1.00 \\
& Glucose & $89.7 \pm 1.7(5)^{*}$ & $0.831 \pm 0.006(5)$ & $7.51 \pm 1.22(5)^{*}$ & 2.06 \\
& Glycine & $88.8 \pm 0.5(5)^{*}$ & $0.812 \pm 0.011(5)$ & $6.52 \pm 0.42(5)^{*}$ & 1.79 \\
\hline \multirow{3}{*}{ Ileum } & Control & $83.0 \pm 1.1(5)$ & $0.807 \pm 0.015(5)$ & $4.37 \pm 0.49(5)$ & 1.00 \\
& Glucose & $92.0 \pm 1.4(5)^{*}$ & $0.779 \pm 0.013(5)$ & $7.65 \pm 0.73(4)^{*}$ & 1.75 \\
& Glycine & $93.0 \pm 1.9(5)^{*}$ & $0.775 \pm 0.013(5)$ & $7.68 \pm 0.97(4)^{*}$ & 1.75 \\
\hline
\end{tabular}

* Statistically different from the controls at the $5 \%$ level.

The number in parentheses indicates the number of observations.

jejunum and ileum were 3.73, 3.64 and $4.37 \mathrm{ml}$ per g dry weight, respectively. These values are in fairly good agreement with those reported hitherto for rabbit ileum 
(SCHULtz et al., 1966) and bullfrog intestines (ARMSTrong et al., 1970, 1975).

Effects of changing $[\mathrm{K}]_{0}$ from 1.0 to $147.2 \mathrm{~mm}$ on the duodenal cell water were reexamined by isotonically replacing $\mathrm{Na}^{+}$(or $\mathrm{K}^{+}$) in the control solution with $\mathrm{K}^{+}$ (or $\mathrm{Na}^{+}$). Changes in the values of $\theta$ were only slight $(81-83 \%$ ), but $\phi$ significantly increases with increasing $[\mathrm{K}]_{\mathrm{o}}$ (Table 2). Such a finding suggests an increase in the cellular volume (i.e., cell swelling) of the epithelial cell with increasing $[\mathrm{K}]_{0}$. Swelling of cells by external high $\mathrm{K}^{+}$has already been reported in the intestinal mucosa (Schultz et al., 1966) as well as in other tissues (KAMINo et al., 1973; LIPTON, 1973). Indeed, there was found a significant increase in the computed value of $V$, as shown in Table 2. Where $[\mathrm{K}]_{0}$ is greater than $69.7 \mathrm{~mm}$, the increases

Table 2. Effect of external $\mathrm{K}^{+}$concentration on the inulin-inaccessible space $(\phi)$ and the cell water content $(V)$ in rat duodenum.

\begin{tabular}{cccc}
\hline $\begin{array}{c}\text { Extracellular } \mathrm{K}^{+} \\
\text {concentration } \\
(\mathrm{mEq} / \mathrm{l})\end{array}$ & $\phi$ & $\begin{array}{c}V \\
\text { (ml/g dry weight) }\end{array}$ & $\begin{array}{c}\text { Relative } \\
\text { swelling }\end{array}$ \\
\hline 1.0 & $0.869 \pm 0.013(6)$ & $3.61 \pm 0.03(10)$ & 0.97 \\
4.2 & $0.877 \pm 0.008(7)$ & $3.73 \pm 0.05(10)$ & 1.00 \\
22.0 & $0.910 \pm 0.011(6)$ & $3.83 \pm 0.03(10)$ & 1.02 \\
69.7 & $0.936 \pm 0.015(7)$ & $4.02 \pm 0.06(10)$ & 1.07 \\
108.5 & $0.957 \pm 0.005(6)$ & $4.30 \pm 0.24(6)$ & 1.15 \\
147.2 & $0.951 \pm 0.002(7)$ & $4.64 \pm 0.09(10)$ & 1.24 \\
\hline
\end{tabular}

The number in parentheses indicates the number of observations.

in $V$ are significant $(P<0.005)$ and appear to vary linearly with $\log [\mathrm{K}]_{0}$, as to the depolarization of membrane potentials of duodenal epithelial cells (OKADA et al., 1976), as shown in Fig. 1. Such a linear relationship between cellular swelling and $\log [\mathrm{K}]_{\mathrm{o}}$ was also reported on isolated synaptosomes (KAMINO et al., 1973).

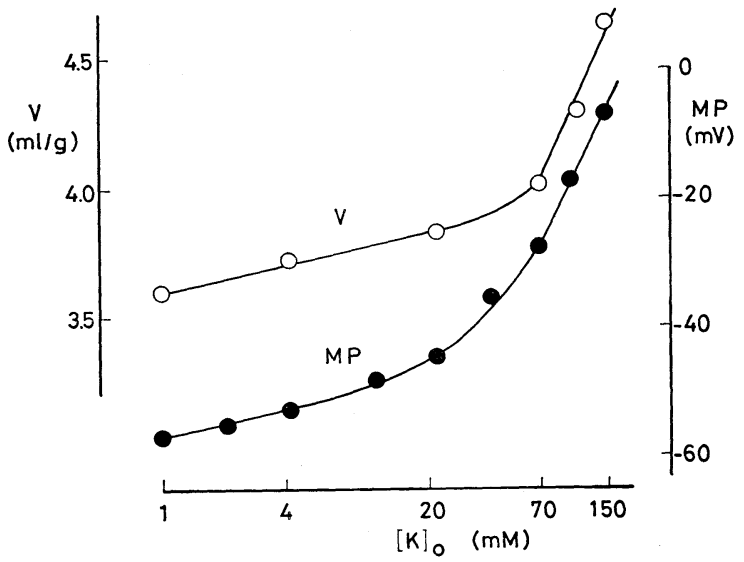

Fig. 1. Plots of changes in the cell water content $(V)$ and the membrane potential (MP) of duodenal epithelial cells related to $\log [\mathrm{K}]_{\mathrm{o}}$. 
When incubated in the medium containing $20 \mathrm{~mm}$ D-glucose or glycine, intestinal tissues became quite watery, and the values of $\theta$ of scraped mucosae concomitantly increased to around $90 \%$ (Table 1). Decreases in their $\phi$ values were also induced by such actively transported solutes, as shown in Table 1. Distension of the lateral intercellular space can be, as already demonstrated in gallbladder epithelia (JoHnson et al., 1962; KAYE et al., 1966; TORMEY and DiAmOND, 1967), expected also in the intestinal epithelia when the active solute transport elevates the solute concentration in this space enough to result in accumulation of water therein. If the activity of the solute transport is high, such an accumulation of water would spread over the subepithelial extracellular space, resulting in expansion of the villous core. Thus the standing-gradient model put forward by Diamond and his school (TORMEY and DiAmond, 1967; DiAmond and Bossert, 1967; DiAMOND, 1971) appears to well account for our observations of the pronounced increases in $\theta$. Since the decreases in $\phi$, however, were not so pronounced compared with the increases in $\theta$, such remarkable increases in $\theta$ induced by D-glucose or glycine should be attributed not only to increases in the extracellular water but also to increases in cell water. In fact, as seen in Table 1, increases in cell water content of epithelial cells $(V)$ induced by the solutes were remarkable. This result is in good agreement with the previous observations made of rabbit ilea (ScHULTZ et al., 1966) and bullfrog intestines (CsÁKY and EsPosito, 1969; ArMSTrONG et al., 1970). It should be noted here that the increases in $V$ shown in Table 1 are quite large (50-100\%) compared with those reported by these investigators, around $12 \%$ in rabbit ilea and around 30 and $15 \%$ in bullfrog intestines. The reason for such a discrepancy is not clear. It may result from differences in the experimental procedures; for example, a lucite frame was used during incubation of tissues in our experiments in order to keep tissues spread and to establish the equilibrium between tissues and the bathing fluid as fast as possible, and then the mucosa was scraped off after incubation for a rather short time $(10 \mathrm{~min})$ in order to keep epithelial cells as intact as possible, while the previous workers used scraped mucosa incubated for $30 \mathrm{~min}$ or more without spreading the tissue.

Many sugars and amino acids are known to be accumulated by intestinal epithelial cells, and their concentrations within the cells can reach more than several times those in the external solutions (SCHULTZ et al., 1966; WISEMAN, 1968; CsÁKY and EsPosito, 1969; Reiser and Christiansen, 1971; MunCK, 1972). The increases in cell water contents induced by such actively transported solutes would, therefore, indicate that these solutes which accumulated within the cell exist in an osmotically active form.

\section{Intracellular monovalent ion concentrations}

The values of $[\mathrm{K}]_{\mathrm{i}},[\mathrm{Na}]_{\mathrm{i}}$ and $[\mathrm{Cl}]_{\mathrm{i}}$ obtained in the duodenum in the control medium were 135,66 and $56 \mathrm{mEq} / \mathrm{kg}$ cell water, respectively, while these values for the jejunum and ileum were not so far from those for the duodenum; 130, 76 and 
$55 \mathrm{mEq}$ in the jejunum and 126, 82 and $83 \mathrm{mEq}$ in the ileum, respectively.

Using duodenal tissues, the effects on the intracellular ion concentrations of changes in $[\mathrm{K}]_{0}$ achieved by isotonical $\mathrm{Na}^{+}-\mathrm{K}^{+}$replacement were reexamined in order to make quantitative comparison with the effects of D-glucose and glycine thereon. All the results obtained in these experiments are summarized in Table 3.

Table 3. Effect of external $\mathrm{K}^{+}$concentration on the intracellular ion concentrations in rat duodenum.

\begin{tabular}{cccccc}
\hline $\begin{array}{c}\text { Extracellular } \mathrm{K}^{+} \\
\text {concentration } \\
(\mathrm{mEq} / \mathrm{l})\end{array}$ & {$[\mathrm{K}]_{\mathrm{i}}$} & {$[\mathrm{Na}]_{\mathrm{i}}$} & {$[\mathrm{Cl}]_{\mathrm{i}}$} & $\mathrm{z}[\mathrm{A}]_{\mathrm{i}}{ }^{*}$ & {$[\mathrm{~B}]_{\mathrm{i}}{ }^{*}$} \\
\hline 1.0 & $125 \pm 4(10)$ & $64 \pm 3(10)$ & $51 \pm 4(10)$ & 138 & 70 \\
4.0 & $135 \pm 8(10)$ & $66 \pm 5(10)$ & $56 \pm 5(10)$ & 145 & 53 \\
22.0 & $144 \pm 4(10)$ & $48 \pm 3(10)$ & $58 \pm 5(10)$ & 134 & 60 \\
69.7 & $174 \pm 6(10)$ & $30 \pm 2(10)$ & $68 \pm 5(10)$ & 136 & 38 \\
108.5 & $188 \pm 5(10)$ & $21 \pm 2(10)$ & $71 \pm 2(10)$ & 139 & 31 \\
147.2 & $188 \pm 2(10)$ & $12 \pm 1(10)$ & $86 \pm 5(10)$ & 114 & 24 \\
\hline
\end{tabular}

* see in detail in the text: $\quad \mathrm{z}[\mathrm{A}]_{\mathrm{i}}=[\mathrm{K}]_{\mathrm{i}}+[\mathrm{Na}]_{\mathrm{i}}-[\mathrm{Cl}]_{\mathrm{i}}$

$$
[\mathrm{B}]_{\mathrm{i}}=\pi-\left\{[\mathrm{K}]_{\mathrm{i}}+[\mathrm{Na}]_{\mathrm{i}}+[\mathrm{Cl}]_{\mathrm{i}}\right\}
$$

The number in parentheses indicates the number of observations made on different animals.

Concordantly with our previous results (OKADA et al., 1976), gradual increases in $[\mathrm{K}]_{\mathrm{i}}$ and $[\mathrm{Cl}]_{\mathrm{i}}$ and a concomitant decrease in $[\mathrm{Na}]_{\mathrm{i}}$ were observed when $[\mathrm{K}]_{\mathrm{o}}$ was elevated. Such changes in the intracellular ion concentrations caused by increases in $[\mathrm{K}]_{0}$ are quite similar to those found on HeLa cells (WICKSON-GINZBURG and Solomon, 1963). It is quite natural that high $\mathrm{K}^{+}$-low $\mathrm{Na}^{+}$media induce increases in $[\mathrm{K}]_{\mathrm{i}}$ and decreases in $[\mathrm{Na}]_{\mathrm{i}}$ while increases in $[\mathrm{Cl}]_{\mathrm{i}}$ are the result of the net flux of $\mathrm{Cl}^{-}$into the cells because of the depolarization of the cell membrane due to high external $\mathrm{K}^{+}$concentration.

Denoting changes in the intracellular ion concentrations as $\pm \Delta$, Fig. 2 shows that $\Delta[\mathrm{K}]_{\mathrm{i}}:-\Delta[\mathrm{Na}]_{\mathrm{i}}: \Delta[\mathrm{Cl}]_{\mathrm{i}}$ is around $4: 3: 1$ except for the points obtained in the isotonic $\mathrm{KCl}$ medium $\left([\mathrm{Na}]_{0}=0,[\mathrm{~K}]_{0}=147 \mathrm{mEq}\right)$, in which the epithelial cell is nearly completely depolarized (OKADA et al., 1976). It follows that the following relation can hold good:

$$
[\mathrm{K}]_{\mathrm{i}}+[\mathrm{Na}]_{\mathrm{i}}-[\mathrm{Cl}]_{\mathrm{i}}=\text { constant }
$$

Of course, $[\mathrm{K}]_{i},[\mathrm{Na}]_{\mathrm{i}}$ and $[\mathrm{Cl}]_{\mathrm{i}}$ may not directly represent their electrochemical ionic activities; the presence of bound or sequestered $\mathrm{Na}^{+}$and $\mathrm{Cl}^{-}$in the intestinal cells have been suggested by some investigators (LEE and ARMSTRONG, 1972; Frizzell et al., 1973). But gain or loss of sequestered $\mathrm{Na}^{+}\left(\right.$or $\left.\mathrm{Cl}^{-}\right)$would result in loss or gain of the negative (or positive) charge within the cell. Thus this relation implies electroneutrality within the cell, when the right-hand side of Eq. (1) stands for the amount of the intracellular negative charges (except for $\mathrm{Cl}^{-}$) referred to the unit amount of cell water, which are in balance with intracellular $\mathrm{K}^{+}$and 


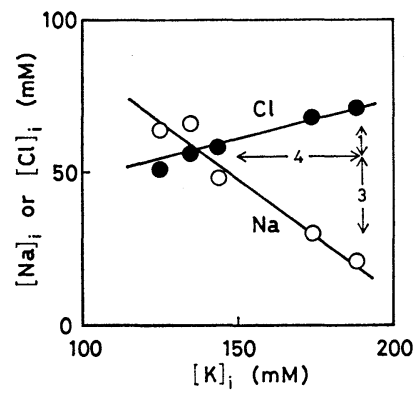

Fig. 2. Interrelationships between changes in $[\mathrm{K}]_{i},[\mathrm{Na}]_{i}$ and $[\mathrm{Cl}]_{\mathrm{i}}$ brought about by high $[\mathrm{K}]_{\mathrm{o}}$.

$\mathrm{Na}^{+}$together with $\mathrm{Cl}^{-}$. Now, if we may assume as the first approximation that there are no significant cations other than $\mathrm{K}^{+}$and $\mathrm{Na}^{+}$and that their charges are balanced with $\mathrm{Cl}^{-}$and intracellular polyvalent anions (A) of their mean valency of $\mathrm{z}$, the total concentration of $\mathrm{A}$ in $\mathrm{mEq}$. could be estimated by giving the righthand side of Eq. (1) as $z[A]_{i}$. Along the same line of reasoning, the restraint of osmotic balance leads us to the following equation, approximately at least:

$$
\pi=[\mathrm{K}]_{\mathrm{i}}+[\mathrm{Na}]_{\mathrm{i}}+[\mathrm{Cl}]_{\mathrm{i}}+[\mathrm{B}]_{\mathrm{i}}
$$

where $\pi$ is the total osmolar concentration in the bathing fluid and $[\mathrm{B}]_{\mathrm{i}}$ is the osmolar concentration of intracellular molecules (B) other than $\mathrm{K}^{+}, \mathrm{Na}^{+}$and $\mathrm{Cl}^{-}$. The values of $z[A]_{i}$ and $[\mathrm{B}]_{\mathrm{i}}$ thus computed are also included in Table 3. As expected, $z[A]_{i}$ remains nearly constant independently of the amount of cell water $(V)$. Since B is mainly, if not solely, composed of indiffusible molecules inside the cell, $[\mathrm{B}]_{\mathrm{i}}$ is expected to decrease with increasing $V$. In fact, as seen in Table 3, computed values of $[\mathrm{B}]_{\mathrm{i}}$ decreased with increasing $[\mathrm{K}]_{\mathrm{o}}$ and also with increasing $V$.

The effects of glucose and glycine on $[\mathrm{K}]_{\mathrm{i}},[\mathrm{Na}]_{\mathrm{i}}$ and $[\mathrm{Cl}]_{\mathrm{i}}$ are summarized in Fig. 3, which clearly shows a tendency for $[\mathrm{Na}]_{i}$ to decrease with concomitant decreases in $[\mathrm{K}]_{i}$ and $[\mathrm{Cl}]_{i}$. The result appears to be contradictory to the well-known fact of $\mathrm{Na}^{+}$entry accompanied by a solute transport (SCHULTZ and CuRRAN, 1970). Indeed, as included in Fig. 3, the concentration of B computed with Eq. (2) increases remarkably, and such an increase in $[B]_{i}$ suggests marked accumulation of glucose or glycine. But such decreases in the monovalent ion concentrations could be explained by increases in cell water brought about by solute accumulation, as has been noted by CSÁKY and EsPosito (1969) or by ARMSTRONG et al. (1970). The intracellular concentration, $C_{j}^{i}$, of $j$-th component $\left(\mathrm{K}^{+}, \mathrm{Na}^{+}, \mathrm{Cl}^{-}\right.$, or B) was referred to the unit amount of the cell water, so that its amount accumulated per unit amount of cell water, $S_{j}$, can be given by

$$
S_{j}=C_{j}^{i}-\left(V^{*} / V\right) \cdot C_{j}^{i *}
$$

where the asterisked symbols imply the quantities observed under the control con- 


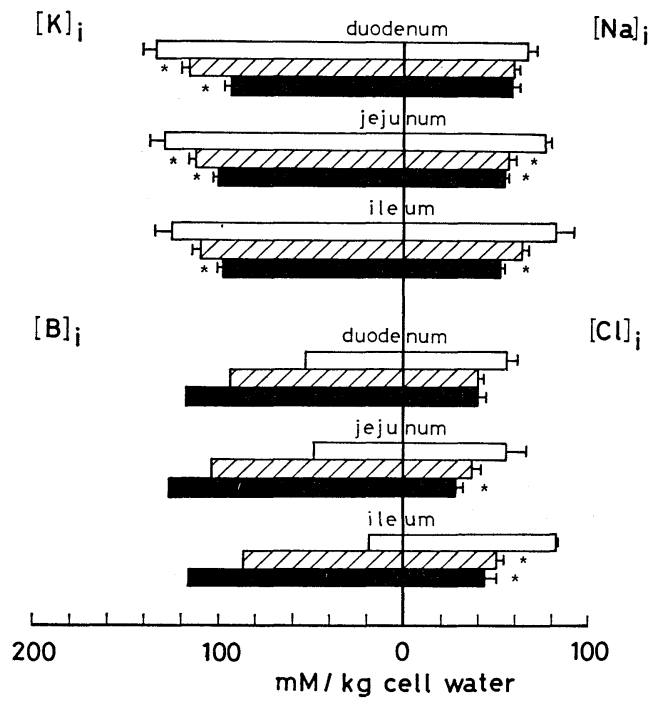

Fig. 3. Effect of $20 \mathrm{~mm}$ solutes on the intracellular monovalent ion concentrations $\left([\mathrm{K}]_{i}\right.$, $[\mathrm{Na}]_{\mathrm{i}}$ and $[\mathrm{Cl}]_{\mathrm{i}}$ ) and on the total concentrations of the other osmotically active molecules $\left([B]_{i}\right)$ in rat small intestine. Hatched and filled columns represent the concentrations in the presence of $20 \mathrm{~mm}$ D-glucose and glycine, respectively. * Statistically different from the control at the $5 \%$ level.

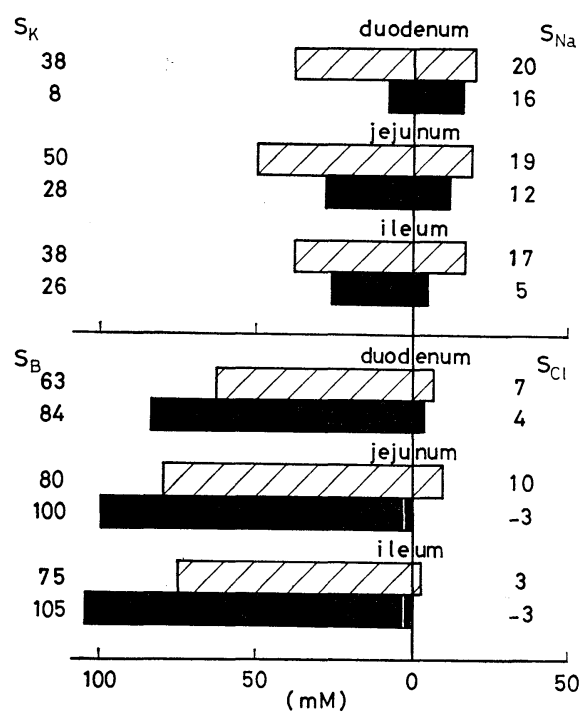

Fig. 4. Net gain of $\mathrm{K}^{+}, \mathrm{Na}^{+}, \mathrm{Cl}^{-}$and $\mathrm{B}$ by epithelial cells produced by $20 \mathrm{~mm}$ D-glucose (hatched column) or glycine (filled column). 
dition (no glucose nor glycine added). The magnitude of $S_{j}$ is easily estimated by applying the values of $C_{j}^{i}$ in Fig. 3 and $V$ in Table 1 . The results are summarized in Fig. 4. $S_{\mathrm{C} 1}$ is small and even negative in some cases (from 10 to $-3 \mathrm{~mm}$ ) and it is difficult, with the accuracy of our analytical methods, to conclude significant gain of $\mathrm{Cl}^{-}$. In contrast to the apparent decreases in $[\mathrm{Na}]_{\mathrm{i}}$ and $[\mathrm{K}]_{\mathrm{i}}$ shown in Fig. 3 , significant net gain of $\mathrm{K}^{+}$and of $\mathrm{Na}^{+}$were brought about by the solute transport (see Fig. 4). Thus the decreases in $[\mathrm{Na}]_{\mathrm{i}}$ and $[\mathrm{K}]_{\mathrm{i}}$ were only apparent ones resulting from the dilution effect. It should be noted here that $S_{\mathrm{K}}$ is greater than $S_{\mathrm{Na}}$. Such a finding suggests a possibility that the greater part of $\mathrm{Na}^{+}$co-transported with the solute is extruded by a $\mathrm{Na}^{+}-\mathrm{K}^{+}$exchange mechanism.

Roughly speaking, changes in $[\mathrm{K}]_{i}$ and $[\mathrm{Na}]_{i}$ induced by the solute transport are linearly related to decreases in $[\mathrm{Cl}]_{\mathrm{i}}$ as illustrated in Fig. 5, which shows $\Delta[\mathrm{K}]_{\mathrm{i}}$ :

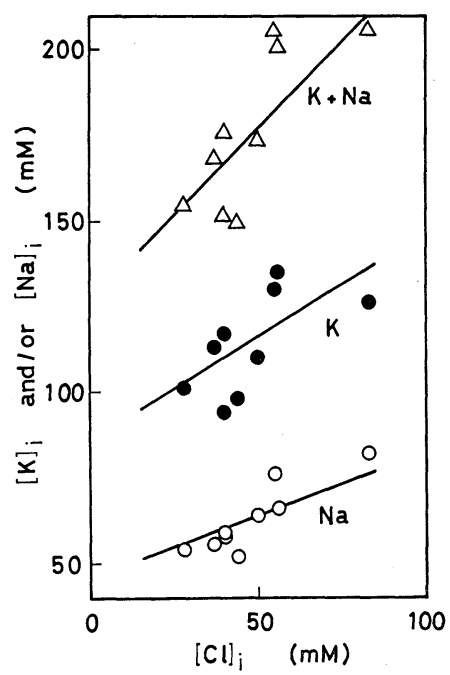

Fig. 5. Interrelationships between changes in $[\mathrm{Cl}]_{i},[\mathrm{Na}]_{i},[\mathrm{~K}]_{\mathrm{i}}$ and $\left([\mathrm{K}]_{\mathrm{i}}+[\mathrm{Na}]_{\mathrm{i}}\right)$ brought about by $20 \mathrm{~mm}$ D-glucose and glycine.

$\Delta[\mathrm{Na}]_{\mathrm{i}}: \Delta[\mathrm{Cl}]_{\mathrm{i}} \simeq 5: 3: 8$. This ratio is quite different not only from that expected from the simple dilution effect $\left(i . e .,[\mathrm{K}]_{\mathrm{i}}:[\mathrm{Na}]_{\mathrm{i}}:[\mathrm{Cl}]_{\mathrm{i}}\right.$ as derived from Eq. (3) by putting $S_{j}=0$ ), but also from that observed with raised external $\mathrm{K}^{+}$(Fig. 2). But $\left(\Delta[\mathrm{K}]_{\mathrm{i}}+\Delta[\mathrm{Na}]_{\mathrm{i}}\right): \Delta[\mathrm{Cl}]_{\mathrm{i}}$ is around unity, so that Eq. (1) might hold as well for the cells accumulating glucose or glycine, at least approximately.

As seen in Figs. 3 and 4, $[\mathrm{B}]_{\mathrm{i}}$ markedly increases and the $S_{\mathrm{B}}$ values are quite high, despite the marked increases in $V$. Such a finding is concordant with the previously reported fact that sugar and amino acids transported uphill into the cells can be concentrated more than several times those in the surrounding media (SCHUltz et al., 1966; Wiseman, 1968; CsÁKy and EsPosito, 1969; ReISER and Christiansen, 1971; MunCK, 1972). Thus, $S_{\mathrm{B}}$ could well be considered to 
represent the amount of solutes accumulated within the cell.

\section{DISCUSSION}

The present study demonstrated that the $\mathrm{K}^{+}$-induced swelling of the intestinal epithelial cells, occurring in parallel with depolarization of the cells (Fig. 1), was chiefly reflected in an increase in the inulin-inaccessible space (Table 2). Applying the Boyle-Van't Hoff relation to such a cell swelling, we have the following relations: for an ideally impermeable component,

$$
C_{j}^{i}\left(V-V_{d}\right)=\text { constant }
$$

where $V_{d}$ is the osmotically dead volume of the cell water for such an impermeable large molecule, and for a component entering with water inflow across the cell membrane and distributing overall the cell water,

$$
C_{j}^{o} d V=V d C_{j}^{i}
$$

where $C_{j}^{o}$ is the external concentration of a $j$-th component. The integration of Eq. (5) results in:

$$
2.3 \cdot \log \left(V / V^{*}\right)=\left(C_{j}^{i}-C_{j}^{i *}\right) / C_{j}^{o}
$$

As shown in Fig. 6a, Eq. (4) holds good for $[\mathrm{B}]_{i}$, a fact providing a strong support

(a)

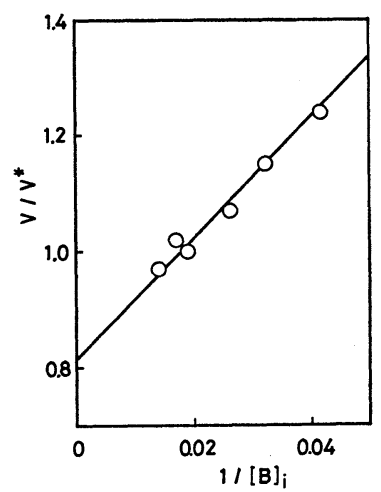

(b)

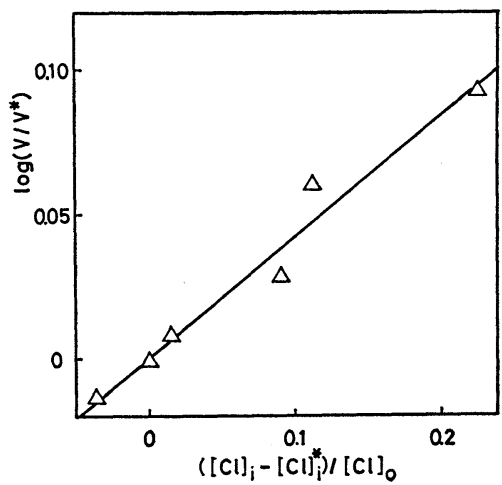

Fig. 6. Relationship between $\mathrm{K}^{+}$-induced swelling and the reciprocal of $[\mathrm{B}]_{\mathrm{i}}$ (a) or the change in $[\mathrm{Cl}]_{\mathrm{i}}(\mathrm{b})$.

for our view that $[\mathrm{B}]_{\mathrm{i}}$ computed by Eq. (2) well reflects the total concentration of indiffusible molecules within the cell. The value of $V_{d} / V^{*}$ estimated from the $y$-intercept for $1 /[\mathrm{B}]_{\mathrm{i}}$ is around 0.8 . This value is considerably higher than the expected one. It may be caused by the slight error in the $[\mathrm{B}]_{\mathrm{i}}$ estimation (Eq. (2)) due to assuming that the measured $[\mathrm{K}]_{\mathrm{i}},[\mathrm{Na}]_{\mathrm{i}}$ and $[\mathrm{Cl}]_{\mathrm{i}}$ represent directly their 
osmotically active concentrations. On the other hand, Fig. $6 \mathrm{~b}$ shows that Eq. (6) is practically applicable to $[\mathrm{Cl}]_{\mathrm{i}}$. This result is concordant with our previous finding that $\mathrm{Cl}^{-}$distributes rapidly and passively $\left(P_{\mathrm{C} 1} \gg P_{\mathrm{K}}\right.$ and $P_{\mathrm{Na}}$ ) (OKADA et al., $1975,1976)$. The cell membrane is permeable to $\mathrm{K}^{+}$and $[\mathrm{K}]_{\mathrm{i}}$ increases as $[\mathrm{K}]_{\mathrm{o}}$ increases, but $[\mathrm{K}]_{\mathrm{o}}$ is always significantly less than $[\mathrm{K}]_{\mathrm{i}}$ (Table 3 ). It is obvious, therefore, that neither Eq. (4) nor Eq. (6) applies for $[\mathrm{K}]_{\mathrm{i}}$. Roughly speaking, a nearly linear relationship is also obtained between $V / V^{*}$ and $1 /[\mathrm{Na}]_{i}$, but its slope is far less steep than that for $1 /[\mathrm{B}]_{i}$, and $V_{d} / V^{*}$ estimated by extrapolation is around 0.9. Such a fact is concordant not only with a low permeability of $\mathrm{Na}^{+}\left(P_{\mathrm{Na}} \lesssim\right.$ $P_{\mathrm{K}}$; OKADA et al., 1975, 1976) but also with the presence of the compartmentalization of this cation inside the epithelial cell, as has been noted previously (LEE and Armstrong, 1972; OKada et al., 1976).

In contrast to the $\mathrm{K}^{+}$-induced swelling, sugar and amino acid transports induced not only increases in $V$ but also increases in extracellular spaces. This fact may be related to the distention of the lateral intercellular space and the villous core during the water transport associated with the solute transport, as noted in the previous section. The solute-induced cell swelling results in decreases in $[\mathrm{K}]_{\mathrm{i}}$ and $[\mathrm{Na}]_{\mathrm{i}}$ (as presented in Fig. 3) despite significant net gain of $\mathrm{K}^{+}$and $\mathrm{Na}^{+}$in the cells (Fig. 4). Nevertheless, $[\mathrm{B}]_{\mathrm{i}}$ never decreases, and $S_{\mathrm{B}}$ is far higher than $S_{\mathrm{K}}$ and $S_{\mathrm{Na}}$. Such a finding indicates that $S_{\mathrm{B}} \cdot V$ well reflects the amount of solutes accumulated within the cell. If the accumulated solutes are osmotically active to increase $V$, the increment of $V(\Delta V)$ would be proportional to $S_{\mathrm{B}} \cdot V$, and so we can expect the following relation using Eq. (4):

$$
k \Delta V=\left(V-V_{d}\right)[\mathrm{B}]_{\mathrm{i}}-\left(V^{*}-V_{d}\right)[\mathrm{B}]_{\mathrm{i}}^{*}=\Delta V[\mathrm{~B}]_{\mathrm{i}}+V^{*} \Delta[\mathrm{B}]_{\mathrm{i}} \cdot\left(1-V_{d} / V^{*}\right)
$$

where $k$ is the proportionality constant. We may rewrite Eq. (7) as follows:

$$
\Delta[\mathrm{B}]_{\mathrm{i}} /\left(\Delta V / V^{*}\right)=\left(1-V_{d} / V^{*}\right)^{-1}\left(k-[\mathrm{B}]_{\mathrm{i}}\right)
$$

Applying the values of $\Delta V / V^{*}$ derived from Table 1, we can easily plot the term of the left-hand side of Eq. (8) against $[B]_{i}$. As shown in Fig. 7, our results are in fair accord with those expected from Eq. (8). The value of $V_{d} / V^{*}$ estimated from the slope of this plot (around 0.7) is not so different from that estimated from Fig. 6a (around 0.8). Such a fact strongly points to the presence of glucose or glycine in an osmotically active form within the cell, which brings about a remarkable cell swelling.

The present experiment clearly showed that the net gain of $\mathrm{Na}^{+}$and $\mathrm{K}^{+}$by the epithelial cells was produced by glucose and glycine, the decreases in $[\mathrm{Na}]_{\mathrm{i}}$ and $[\mathrm{K}]_{\mathrm{i}}$ being only apparent ones due to the cell swelling. Such a finding is concordant with the well-known fact that the uphill transport of organic solutes is linked with entry of $\mathrm{Na}^{+}$across the brush border membrane (SCHULTZ and CuRRAN, 1970; HosHI, 1972); an electrogenic Na pump located on the basolateral membrane 
(OKADA and INOUYE, 1976; Okada et al., in preparation) extrudes $\mathrm{Na}^{+}$and gains $\mathrm{K}^{+}$. The coupling ratio of $\mathrm{Na}^{+}$-efflux to $\mathrm{K}^{+}$-influx of this pump in rat duodenum was estimated as 4: 3 or more (OKADA and INOUYE, 1976; Okada et al., in preparation). Thus, it is not so difficult to understand why the net gain of $\mathrm{K}^{+}$should be greater than that of $\mathrm{Na}^{+}$as seen in Fig. 4.

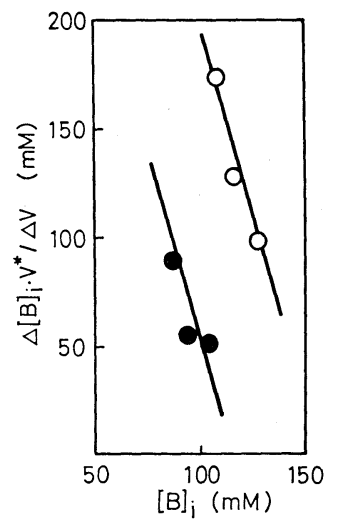

Fig. 7. Plot of the values of $\Delta[\mathrm{B}]_{\mathrm{i}} \cdot V^{*} / \Delta V$ against the $[\mathrm{B}]_{\mathrm{i}}$ values in the presence of $20 \mathrm{mM}$ D-glucose ( ) or glycine $(O)$ in the bathing fluid.

As is noted above, the behavior of intracellular $\mathrm{Cl}^{-}$in cell swelling produced by glucose (or glycine) appears to be passive, but it forms a striking contrast to that in the $\mathrm{K}^{+}$-induced swelling; $[\mathrm{Cl}]_{i}$ is reduced in the former, but raised in the latter. A significant depolarization of the cell brought about by high external $\mathrm{K}^{+}$results in an increase in the electrochemical gradient for $\mathrm{Cl}^{-}$across the brush border membrane which enables the ions to flow into the cells. In the presence of $20 \mathrm{~mm}$ glucose (or glycine), however, the measured mucosal membrane potentials are only slightly depolarized (less than $5 \mathrm{mV}$ ) (OKADA and INOUYe, 1976). Lacking in any significant depolarization of the cell membrane, therefore, increases in the intracellular $\mathrm{Cl}^{-}$concentration would not be so large. Moreover, the activity of the sodium pump enhanced by the entry of $\mathrm{Na}^{+}$associated with the solute transport might produce to a certain extent the extrusion of $\mathrm{Cl}^{-}$with $\mathrm{Na}^{+}$. Our finding of $S_{\mathrm{C} 1} \simeq 0$ in the presense of solutes appears to be consistent, despite the high permeability of $\mathrm{Cl}^{-}$.

Several investigators have reported a small depolarization of the membrane potential of the intestinal cell during an uphill solute transport (Rose and SCHULTZ, 1971; White and Armstrong, 1971; OKada and Inouye, 1976). Applying the Goldman equation, the apparent ionic permeabilities of the cell membrane under control conditions (without glucose and glycine) were estimated to be $P_{\mathrm{C} 1} / P_{\mathrm{K}} \gg 1$ and $P_{\mathrm{Na}} / P_{\mathrm{K}} \simeq 0.1$ (OKADA et al., 1975, 1976). The changes in the intracellular ion concentrations produced by glucose or glycine (Fig. 3) would bring about the de- 
polarization of about $5-10 \mathrm{mV}$, if the solute transport does not significantly affect the passive permeability properties of these ions. When an electrogenic sodium pump is located on the serosal membrane (OKADA and INOUYE, 1976; Okada et al., in preparation) and is activated by the $\mathrm{Na}^{+}$gain within the cell, however, a hyperpolarization of the serosal membrane would be concurrently produced, counteracting to a certain extent such a depolarization (OKADA and INOuYE, 1976). Thus our results are also concordant with the electrophysiological studies reported hitherto.

This work was supported in part by grant from the Ministry of Education, Science and Culture, of Japan.

\section{REFERENCES}

Armstrong, W. McD., Byrd, B. J., Cohen, E. S., Cohen, S. J., Hamang, P. H., and Myers, C. J. (1975) Osmotically induced electrical changes in isolated bullfrog small intestine. Biochim. Biophys. Acta, 401: 137-151.

Armstrong, W. McD., Musselman, D. L., and Reitzug, H. C. (1970) Sodium, potassium, and water content of isolated bullfrog small intestine epithelia. Am. J. Physiol., 219: 1023-1026.

Barry, R. J. C., Dickstein, S., Matthews, J., Smyth, D. H., and Wright, E. M. (1964) Electrical potentials associated with intestinal sugar transport. J. Physiol., 171: 316-338.

CsÁky, T. Z. and Esposito, G. (1969) Osmotic swelling of intestinal epithelial cells during active sugar transport. Am. J. Physiol., 217: 753-755.

Diamond, J. M. (1971) Standing-gradient model of fluid transport in epithelia. Fed. Proc., 30: 6-13.

DiAmond, J. M. and Bossert, W. H. (1967) Standing-gradient osmotic flow. A mechanism for coupling of water and solute transport in epithelia. J. Gen. Physiol., 50: 2061-2083.

Frizzell, R. A., Nellans, H. N., Rose, R. C., Markscheid-Kapsi, L., and Schultz, S. G. (1973) Intracellular $\mathrm{Cl}$ concentrations and influxes across the brush border of rabbit ileum. Am. J. Physiol., 224: 328-337.

Hoshi, T. (1972) The active transport of sugar by the small intestine and renal tubule: Its $\mathrm{Na}^{+}$dependence and the sugar-transport potentials. Seitai no Kagaku, 23: 69-88 (in Japanese).

Hoshi, T. and Komatsu, Y. (1968) Sugar-evoked potential in isolated toad intestine. Jap. J. Physiol., 18: 508-519.

Johnson, F. R., McMinn, R. M. H., and Birchenough, R. F. (1962) The ultrastructure of the gall-bladder epithelium of the dog. J. Anat. (Lond.), 94: 477-487.

Kamino, K., InouYe, K., and INOuYe, A. (1973) Potassium ion-induced swelling of nerve-ending particles by light-scattering measurement. Biochim. Biophys. Acta, 330: 39-52.

KAYe, G. I., WheEler, H. O., Whitlock, R. T., and LANE, N. (1966) Fluid transport in the rabbit gallbladder. A combined physiological and electron microscopic study. J. Cell Biol., 30: 237-268.

Koopman, W. and Schultz, S. G. (1969) The effect of sugars and amino acids on mucosal $\mathrm{Na}^{+}$ and $\mathrm{K}^{+}$concentrations in rabbit ileum. Biochim. Biophys. Acta, 173: 338-340.

LeE, C. O. and Armstrong, W. McD. (1972) Activities of sodium and potassium ions in epithelial cells of small intestine. Science, 175: 1261-1264.

LiPTON, P. (1973) Effects of membrane depolarization on light scattering by cerebral cortical slices. J. Physiol., 231 : 365-383.

Lyon, I. and Crane, R. K. (1966) Studies on transmural potentials in vitro in relation to intestinal absorption. I. Apparent Michaelis constants for $\mathrm{Na}^{+}$-dependent sugar transport. Biochim. Biophys. Acta, 112: 278-291. 
MuncK, B. G. (1972) Amino acid transport by rat small intestine. Galactose inhibition of transepithelial net transport as a result of stimulation of bidirectional efflux from the epithelium. Biochim. Biophys. Acta, 266: 639-648.

OKADA, Y. and INOUYE, A. (1976) Electrical properties and ionic permeabilities in rat small intestine. Seibutsu Butsuri (in press) (in Japanese).

Okada, Y., IRIMAJIRI, A., and INOUYe, A. (1976) Permeability properties and intracellular ion concentrations of epithelial cells in rat duodenum. Biochim. Biophys. Acta, 436: 15-24.

OKadA, Y., SATo, T., and INOUYE, A. (1975) Effects of potassium ions and sodium ions on membrane potential of epithelial cells in rat duodenum. Biochim. Biophys. Acta, 413: 104 115.

Reiser, S. and Christiansen, P. A. (1971) The properties of the preferential uptake of L-leucine by isolated intestinal epithelial cells. Biochim. Biophys. Acta, 225: 123-139.

Rose, R. C. and SChULTZ, S. G. (1971) Studies on the electrical potential profile across rabbit ileum. Effects of sugars and amino acids on transmural and transmucosal electrical potential differences. J. Gen. Physiol., 57: 639-663.

Schultz, S. G. and Curran, P. F. (1970) Coupled transport of sodium and organic solutes. Physiol. Rev., 50: 637-718.

Schultz, S. G., Fuisz, R. E., and Curran, P. F. (1966) Amino acid and sugar transport in rabbit ileum. J. Gen. Physiol., 49: 849-866.

SChULTZ, S. G. and ZALUSKY, R. (1964) Ion transport in isolated rabbit ileum II. The interaction between active sodium and active sugar transport. J. Gen. Physiol., 47: 1043-1059.

ToRmey, T. McD. and Diamond, J. M. (1967) The ultrastructural route of fluid transport in rabbit gall bladder. J. Gen. Physiol., 50: 2031-2060.

White, J. F. and ARMSTRong, W. McD. (1971) Effect of transported solutes on membrane potentials in bullfrog small intestine. Am. J. Physiol., 221: 194-201.

Wickson-Ginzburg, M. and Solomon, A. K. (1963) Electrolyte metabolism in HeLa cells. $J$. Gen. Physiol., 46: 1303-1315.

WiLson, T. H. (1962) Intestinal Absorption, W. B. Sanders Company, Philadelphia.

Wiseman, G. (1968) Absorption of amino acid. In: Handbook of Physiology, Sec. 6 Vol. III. American Physiological Society, Washington, D. C., pp. 1277-1307. 